\title{
EVALUATION OF PEACH HYBRIDS USING SOME POMOLOGICAL CHARACTERS AND RAPD MARKERS
}

\author{
El-Morshedy. F. A., M. I. Salama, Hamdia M. Ayaad and A. E. \\ Abdelmonem \\ Horticulture Dept., Faculty of Agriculture, Kafrelsheikh Univ., Egypt
}

\begin{abstract}
This research was carried out in 2014 and 2015 seasons, to evaluate the pomological characters such as bud burst, full bloom, fruit set, ripening date and fruit quality of ten peach hybrids grown under Egyptian conditions. In addition, the random amplified polymorphic of DNA (RAPD) to produce a dendrogram of genetic relationships among peach hybrids. The results indicated that hybrids, 5 and 6 had the earliest bud burst and full bloom than all tested hybrids, on the other hand, hybrid 1 and 8 had the latest one in two successive seasons. Hybrid 4 in the first season and both of hybrids 5 and 6 in the second season had the ripening date early than all tested hybrids, while, hybrid 10 and 1 in both seasons had the latest ripening date. Hybrids 9 and 10 fruits had the highest fruit firmness than the other hybrids. While, fruit size was $63.53 \mathrm{~cm}^{3}$ and $82.86 \mathrm{~cm}^{3}$ for hybrids 7 and 10 , successively. Hybrids 9 and 10 had heavier fruit, stone and flesh weight than all tested hybrids, whereas, hybrid 7 the lowest one and the situation is reflected in flesh/stone ratio. In both seasons, hybrid 3 had the highest SSC as compared with all tested hybrids, while hybrids 1 and 6 had the lowest ones. Hybrid 1 had the highest acidity as compared with all tested hybrids, while hybrid 3 had the lowest percent. On the contrary, hybrid 3 had higher SSC/ratio, while hybrid 1 had the lowest ones. In addition to, hybrid 7 had the highest ascorbic acid with the other hybrids, hybrid 3 had the lowest ones. The dendrogram indicated that the ten tested hybrids were classified into two main clusters. Cluster I included hybrids 9 and 10 . The cluster II was divided in to two subclusters, sub-cluster I contained hybrids 1 and 3 and sub-cluster II divided into two groups, group II included hybrids 6 and 8 and group I divided into two sub-groups, sub-group I divided in to two sub sub groups, sub sub group I included hybrids 2 and 5 and sub sub group II included hybrid 4 and subgroup II included hybrid 7.
\end{abstract}

Key words: prunus, hybrids, peach, RAPD, dendrogram.

\section{INTRODUCTION}

Peach (Prunus persica L. Batsch) is one of the most important species of genus prunus and family "Rosaceae" which is originated in China, there are many peach cultivars growing more widely now throughout the world. Peach is one of the most important and successful deciduous fruits grown in Egypt. According to (FAO, 2014) the total planted area of peach and nectarine increased rapidly through 
the last decades. It reached about 113070 hectare produced 290001 tons/year. Peach is highly demanded by Egyptian consumer, peaches are eaten fresh, canned or dried and are excellent sources of fibers, vitamins and antioxidants. The peach and nectarine are primarily grown in temperate zones, between latitudes $30 \mathrm{~N}$ and $45 \mathrm{~S}$. These cultivars require from 100 to 1000 hours of chilling. Egypt lines in the sub-tropical zone between $22^{\circ}$ to $30^{\circ}$ latitudes, chilling hours varying between 150-300 hours in most production area. Peach cultivars are early, medium or late season with good fruit characteristics and had been adapted to our local climate such as Florida Prince, thus are the most dominate cultivars due to its earliness, good firmness and color (Shaltut, 2003). Furthermore, in Egypt there were some seedy plantations of local (Meet Ghamr) cultivar which is the principle cultivar, thus was more adapted to local environmental condition with a special taste, aroma and appear in markets in late season (Eliwa, 2005). Moreover, peach is considered the best genetically characterized species of the genus, the structure and organization of nuclear genome of Prunus species are poorly understood. In peach breeding program, to select fruit specific characters, trees must be maintained until fruiting, usually after 3-4 years (Sherman and Lyrene, 1983), this process as expensive and time-consuming. Peach is a self-pollinated diploid $(2 n=16)$ and has a small genome. Both a low base chromosome number and a small genome size make peach a suitable model to study genome organization. Random amplified polymorphic DNA markers (RAPD) provide new sources of numbers of molecular markers. Screening and mapping RAPD markers is relatively easy, but in contrast to $R F L P_{s}$ (Restriction Fragment Length Polymorphism) and isozyme, RAPD are dominating markers. RAPD have been used to develop extensive apple (Weeden et al, 1991). For these reasons, molecular markers linked to these traits have great a utility for identification of the plant genotype well before the traits are expressed.

\section{MATERIALS AND METHODS}

\section{Plant materials and treatments}

This study was conducted during two successive growing seasons of 2014 and 2015 at a private orchard located at El-Saad village, ElNoubaria region, El-Behera governorate, on ten years old peach hybrids unknown parents (Prunus persica L.) spaced at $4 \times 4$ meters apart. The trees received the normal horticultural practices usually adapted for this area (irrigation, fertilization, pruning and pest control). Thirty trees were chosen according to their similarity in vigor and uniform as possible. Each hybrid (treatment) was represented by three 
trees as replicates with one tree for each (10 hybrids $\times 3$ replicates $\times 1$ tree $=30$ trees). The studied trees were arranged in random complete blocks design (RCBD) Snedecor and Cochran (1967).

The following parameters were determined during the two growth seasons

\section{Flowering and fruiting measurements}

The bud burst and full bloom date were registered for each hybrid. The fruit set percentage calculated using this equation (Fruit set $\%=($ No. of fruit set $/$ No. of flower at full bloom) $\times 100)$. The ripening date was recorded according to the harvesting date for each hybrid.

\section{Fruit quality}

Random samples of 10 fruits were taken from each tree for measuring their physical properties:

Fruit weight $(\mathrm{g})$, fruit size was measured by size banter $\left(\mathrm{cm}^{3}\right)$, fruit dimension (diameter, length $(\mathrm{cm})$ and fruit shape index $L / D$ ), fruit firmness (using the Magnus pressure tester expressed as $1 \mathrm{~g} / \mathrm{cm}^{2}$ ), fruit stone weight $(\mathrm{g})$, fruit flesh weight $(\mathrm{g})$ and fruit flesh thickness was determined using the ruler from the fruit skin to the pit $(\mathrm{cm})$.

\section{Chemical fruit constituents}

Soluble solids contents (SSC \%) was determined by hand refractometer, fruit juice titratable acidity was expressed as percent malic acid (A. O. A. C, 1980), Soluble solids contents / titratable acidity ratio was calculated as ratio between SSC and acidity percentage and vitamin C. (ascorbic acid) was determined in filtered juice samples and expressed as mg/100 ml juice as described by (A. O. A. C, 1980).

\section{Statistical Analysis:}

All obtained data were statistically analyzed using a randomized complete block design according to Snedecor and Cochran (1967).

\section{Identification of peach cultivars by RAPD marker}

Plant material: PCR analysis was carried out using genomic DNA of peach hybrids.

DNA isolation: DNA of ten peach hybrids was isolated using CTAB method from fresh leaves according to Doyle and Doyle (1990).

\section{Data Analysis}

Amplification profiles for the used ten peach genotypes as a result of RAPD application were compared with each other and DNA fragments were scored as a binary data, where (1) means presence and (0) means absence. Data were used to estimate genetic similarity 
on the basis of number of shared amplification products. The distance coefficients were calculated by the following statistical equation.

$$
\mathrm{F}=2 \mathrm{~N}_{\mathrm{xy}} /\left(\mathrm{N}_{\mathrm{x}}+\mathrm{N}_{\mathrm{y}}\right)
$$

Where, $F$ is the distance coefficient in which $N_{x}$ and $N_{y}$ are the numbers of fragments in genotypes $x$ and $y$, respectively, and $N_{x y}$ is the number of fragments differed by the two genotypes. The electrophoretic patterns of the reproducible banding patterns of each primer which produced by RAPD were chosen for analysis. Each band was scored as present (1) or absent (0), and pairwise comparisons between individuals were made to calculate the Jukes-Cantor coefficient using PAST program (Paleontological Statistics Version 1.94b) adapted by Hammer et al. (2001). Cluster analysis was performed to produce a denderogram using unweight pair-group method with arithmetical average (UPGMA).

\section{Flowering and fruiting measurements \\ RESULTS AND DISCUSSION \\ 1.1. Bud Burst}

The present results revealed that hybrids 6 (25 Jun) and 5 (20 Jun) had the earliest bud burst, on the other hand, hybrids 8 (18 Feb) and 7 (13 Feb) had the latest bud burst comparing to all tested hybrids in two successive seasons (Table 1). These findings are in agree with those of Stino et al. (1982) who found that floral bud burst stage began on the first week of February on local peach cv. Meet Ghamr, while Stino and Mansour (1985) stated that the floral bud burst of Rio Grande, Early Amber and Spring Crest peach cultivars started at the first week of March, the third week of February and the second week of March, respectively.

\subsection{Full bloom}

The earliest full bloom given by hybrids 2 and 6 (24 Feb) as well as hybrid 5 (18 Feb), whereas, hybrid 1 (23 Mar) and both of hybrids 3 and 8 (15 Mar) recorded the latest full bloom date in the first and second seasons, successively (Table 1). These observations are in harmony with Emad-Eldin et al. (2012) who observed that the full bloom date ranged from 22 Feb to 15 Mar and 27/ Feb to 14 Mar for some $\mathrm{F} 1$ peach seedlings in the two successive seasons. The full bloom date ranged from 6 Feb to 21 Feb in the first season and it was $5 \mathrm{Feb}$ to 20Feb in the second one for some peach selected strains (Fathi et al, 2013. b).

\subsection{Fruit Set (\%)}

The present results observed that hybrid $6(39.00 \%)$ in the first season recorded the highest significantly value as compared with other 
hybrids. While, hybrids $10(24.00 \%)$ and $3(24.40 \%)$ had the lowest average fruit set percentage in first and second seasons, respectively (Table 1). The results are an analogous of those found by Fathi et al. (2013. b) who revealed that the highest and the lowest value of fruit set were $(28.0 \& 40.27 \%)$ and $(28.33$ \& $45.80 \%)$ for some peach selected strains in two successive seasons. Also, Citadin et al. (2014) who showed that fruit set was ranged from 17.6 to $77.0 \%$ for peach trees in a subtropical climate.

\subsection{Ripening date:}

The results showed that, in the first season, hybrid 4 (23 May) had the earliest fruit ripening date followed by hybrids 2, 5 and 6 (30 May). Whereas, hybrids 7 and 10 (29 Jun) recorded the latest fruit ripening date. The analogous data in the second season, indicated that both of hybrids 5 and 6 (30 May) as well as hybrid 1 (30 Jun) recorded the earliest and the latest fruit ripening date, respectively (Table 1). These results are in semi-accordance with those obtained by El-Shekh (2001) who reported that harvest date of Desert Red peach cultivar was 3 May and 5 May in the two successive seasons and Dinesh et al (2014) who noticed that time of maturity fell between 7 May in Tropic Snow to 5 June for Tropic Sweet, Early Grande and Pratap peach cvs.

\section{Fruit physical characters}

\subsection{Fruit weight (g)}

The results showed that the highest values of fruit weight were obtained by both of hybrids 9 (95.11 g.) and 10 (95.88 g.) as well as hybrid 10 (97.35 g.) followed by hybrid 9 (93.77 g.) in 2014 and 2015 seasons, respectively. While, in both experimental seasons hybrid 7 had the lowest fruit weight values (80.15 and $80.08 \mathrm{~g}$.) (Table 2). Variations in fruit weight among various hybrids in this study were in agreement with other investigators such as Holub and lolar (1980), they examined several peach cvs. and mentioned that fruit weight of peach cultivars was ranged from 68 to $210 \mathrm{~g}$. Moreover, Eliwa (2005) found that the Mawy peach cv. presented the highest fruit weight (109.30 and 120.60 g.), while Fark peach cv. gave the lowest value (87.80 and $84.22 \mathrm{~g}$.$) in the two seasons.$

\subsection{Fruit size $\left(\mathrm{cm}^{3}\right)$}

In both growing seasons, the results cleared that, hybrid 10 had the highest fruit size $\left(82.26\right.$ and $\left.82.86 \mathrm{~cm}^{3}\right)$ as compared with the other tested hybrids followed by hybrid 9 . On the other hand hybrid 7 had the lowest one $\left(66.13\right.$ and $63.53 \mathrm{~cm}^{3}$ ) (Table 2). These results are in line with those of Gawiesh (2009) who indicated that fruit size ranged from 53.53 to $126.573 \mathrm{~cm}^{3}$ for some peach hybrids. The fruit size was 66.51 
and $50.94 \mathrm{~cm}^{3}$ for May fire and Nectared 4 nectarine cultivars, successively (Tomo et al, 2012).

\subsection{Fruit length $(\mathrm{cm})$}

The results of both experimental seasons revealed that hybrid 10 recorded the significantly highest fruit length $(6.33$ and $6.29 \mathrm{~cm})$ as comparing with the other hybrids except hybrid $5(6.37 \mathrm{~cm})$ in 2014 season, thus followed by hybrid $3(6.09$ and $6.01 \mathrm{~cm})$. Furthermore, the lowest values were obtained by hybrid $8(4.55 \mathrm{~cm})$ as well as hybrids 2,7 and $9(4.81 \& 4.75$ and $4.77 \mathrm{~cm})$ in the two successive seasons (Table 2 ).

\subsection{Fruit diameter $(\mathrm{cm})$}

The results cleared that, in 2014 season, hybrids 3, 5 and 10 (6.39 \& 6.40 and $6.39 \mathrm{~cm}$ ) had significantly highest fruit diameter than the other hybrids, whereas hybrid $4(4.81 \mathrm{~cm})$ and $8(4.85 \mathrm{~cm})$ had the lowest diameter. As for, in 2015 season, the significant highest fruit diameter value was given by hybrid $10(6.33 \mathrm{~cm})$ followed by hybrids 1 , 5 and 8. Whereas, the lowest fruit diameter obtained by hybrid 3 (4.89 cm) (Table 2).

\subsection{Fruit shape index $L / D$ ratio}

In 2014 season the results showed that, hybrid 4 had significant length/diameter ratio (1.002) as compared to the other hybrids, whereas hybrid 6 showed the lowest value (0.92). The results cleared that, in 2015 season, hybrid 3 had the highest significantly length/diameter ratio (1.22) and trend to be oblong shape as compared to the other hybrids, whereas hybrid 2, 7 and 9 showed the lowest value. The values of $L / D$ ratio ranged from 0.89 to 0.99 for the other hybrids in two successive seasons, this indicated that almost fruits shape was round (Table 2).

In this sphere, Sharpe (1971) cleared that the diameter of Florida Belle peach cultivar reached to 2.5 inch. The fruit diameter and length of Florida Prince, Florida Belle and Florida Beauty peach cultivars was $(5.22 \& 5.60$ and $5.76 \mathrm{~cm})$ and $(3.03 \& 6.20$ and $6.44 \mathrm{~cm})$ successively (Aly, 1988). As for Gawiesh (2009) obtained that fruit length, diameter and fruit shape index ranged from 4.05 to $6.573 \mathrm{~cm} \& 4.05$ to $5.957 \mathrm{~cm}$ and 0.939 to 1.113 for some peach hybrids, respectively.

\subsection{Fruit firmness $\left(\mathrm{g} / \mathrm{cm}^{2}\right)$}

In the first season, the results showed that, the significant highest value of fruit firmness obtained by hybrids 1,9 and $10(469 \& 475$ and $481 \mathrm{~g} / \mathrm{cm}^{2}$, respectively) while, the lowest value given by hybrid 5 (304 $\mathrm{g} / \mathrm{cm}^{2}$ ). Furthermore, hybrids $4,6,7$ and 8 had similar fruit firmness. In 
the second season, each of hybrids 6,9 and 10 had significantly higher fruit firmness (456 \& 476 and $473 \mathrm{~g} / \mathrm{cm}^{2}$, respectively) as compared with the hybrids. Moreover, both of hybrids $2\left(336 \mathrm{~g} / \mathrm{cm}^{2}\right)$ and $5\left(328 \mathrm{~g} / \mathrm{cm}^{2}\right)$ recorded the lowest values (Table 3$)$. In this concern, Watada et al. (1976) recorded that the fruit firmness of Rio Oso Gem peach cv. was $15 \mathrm{lb} / \mathrm{inch}^{2}$ and Fahmy et al. (2015) indicated that fruit firmness ranged from 2.93 to $5.40 \mathrm{Lb}$. $/$ inch $^{2}$ in Florida Prince peach cv.

\subsection{Seed weight (g)}

The results cleared that, during both seasons, hybrid 10 had the highest significantly seed weight ( 7.93 and $8.12 \mathrm{~g}$.) as compared to the other hybrids except hybrid 9 in the first season, while hybrid 7 had markedly lower seed weight (5.01 and 5.03 g.) except hybrid 8 in 2014 season (Table 3). These findings are in accordance with those of Fathi et al. (2013. b) who stated that fruit seed weight was 4.12 and $6.59 \mathrm{~g}$. for $\mathrm{K} 3$ and $2 \mathrm{~L}$ peach strains, respectively. Whereas, Jana (2015) observed that fruit seed weight was 2.86 and $7.62 \mathrm{~g}$. for Florida sun and Prabhat peach cultivars, successively.

\subsection{Flesh weight $(g)$}

Data cleared that the significant highest value resulted from both of hybrids 9 (87.92 g.) and 10 (87.95 g.) also hybrid 10 (89.23 g.) followed by hybrids 3 and 9 in the two successive seasons. While, in both seasons, the lowest value obtained by hybrid 7 (75.14 \& $75.06 \mathrm{~g}$.) (Table 3). The above results are in agreement with those reported by Ezz, and El-Kobbia (2000), they showed that Early Grande fruit flesh weight was 67.68 and $65.62 \mathrm{~g}$. in the first and second seasons, successively. While, Gawiesh (2009) revealed that the flesh weight for some peach hybrids was ranged from 35.23 to $104.97 \mathrm{~g}$.

\subsection{Flesh/seed ratio}

In the first season, hybrid 7 recorded the highest value (15.00) comparing to the other hybrids, the lowest values had remarkable of flesh/seed ratio recorded hybrid 10 . In the second season, hybrids 3 , 6,7 and 8 given approachable flesh/seed ratio. No significant differences were observed between hybrids 1,2 and 9 and also among 4, 5 and 10 (Table 3). The results confirmed the observation of Haikal (2005) who reported that the highest value of flesh/seed ratio presented by Hegazy (12.07) and Fla 16/33 (25.66) peach cultivars in 2003 and 2004 seasons, respectively, the Tejon peach cultivars had the lowest values (10.33 and 11.14) for the experimental successive seasons. As for, Jana (2015) noticed that flesh/seed ratio was 2.544 and 6.382 for Prabhat and Florida sun peach cultivars, successively. 


\subsection{Flesh thickness (cm)}

In the first season, the results showed that, each of hybrids 3, 6, 9 and 10 recorded the highest significantly flesh thickness $(1.82 \& 1.81 \&$ 1.91 and $1.92 \mathrm{~cm}$ ) as compared with the other hybrids, while hybrid 7 had remarkably lower flesh thickness $(1.38 \mathrm{~cm})$. No significant differences were found among hybrids $1,2,4$ and 5 . In the second season, the results cleared that hybrid 3 had markedly the highest flesh thickness $(1.93 \mathrm{~cm})$ as compared with the other tested hybrids followed by each of 1, 4, 6, 9 and 10, had the same letters. Whereas both of hybrids $2(1.54 \mathrm{~cm})$ and $7(1.54 \mathrm{~cm})$ had significantly lower flesh thickness (Table 3). Similar pattern of flesh thickness was observed by Gawiesh (2009) who cleared that flesh thickness ranged from 1.367 to $1.960 \mathrm{~cm}$ for some peach hybrids and Fathi et al. (2013. b) who obtained that fruit flesh thickness was 1.60 and $1.76 \mathrm{~cm}$ for K3 and X2 peach strains, respectively.

\section{Fruit chemical characters}

\subsection{Soluble solids content (SSC \%)}

In both season, hybrid 3 had the highest soluble solids contents (13.33 and $13.43 \%)$ except hybrid 8 . While, hybrids 1 (9.33 and $9.56 \%)$ and $6(9.50$ and $9.50 \%)$ had the lowest values. Furthermore, there were no markedly different in SSC of hybrids 2, 4, 9 and 10 in the first season, as well as hybrids 2, 9 and 10 also among 4 and 5 in the second season (Table 4). The variations among the studied hybrids supported the findings previously reported by many other investigators such as Fathi et al. (2013. a) who indicated that SSC ranged from 11.6 to 16 ${ }^{\circ}$ Brix in some new peach genotypes, while, Cirilli et al. (2016) tested some new peach genotypes, they stated that the SSC ranged from 9.7 to $13.9 \%$.

\subsection{Acidity (\%)}

In both seasons, hybrid 1 had the highest significant acidity $(0.755$ and $0.745 \%)$ followed by hybrid $6(0.710$ and $0.729 \%)$, whereas hybrid 3 had the lowest value $(0.485$ and $0.520 \%$ ) (Table 4$)$. Similar trend was found throughout the work of Shinya et al. (2014) who found that the fruit acidity were 0.37 and $0.90 \%$ for Royal Glory and Elegant Lady peach varieties, successively. As well as it was 1.20 and $0.91 \%$ for Ruby Diamond and Venus nectarine varieties, respectively. While, Abidi (2016) stated that remarkable differences among fruit peach cultivars in acidity levels, were $0.51 \%$ in 'UFO 4' and $0.76 \%$ in 'Vio white 5'. 


\subsection{SSC / Acid ratio}

The results revealed that, in both seasons, hybrid 3 had the highest SSC/Acid ratio than the other hybrids (27.49 and 25.80), whereas hybrids 1 (12.35 and 12.84) and 6 (13.37 and 13.02) had the lowest values. No significant differences were found among hybrids 5,7 and 9 in the first season also among 2, 8 and 10 in the second season (Table 4). These results are an analogous of those found by Ahmed (2005) who observed that SSC/acidity ratio for Desert Red peach cultivar was 13.775 and 15.007 for the two successive seasons. Whereas, Fahmy et al. (2015) showed that the fruit SSC/Acid ratio ranged from 5.02 to 17.08 in Florida prince peach cv.

\subsection{Ascorbic acid / Vitamin C ( $\mathrm{mg} / 100 \mathrm{ml})$}

The results indicated that, in both seasons, hybrid 7 had significantly the highest content ascorbic acid $(9.60$ and $10.27 \mathrm{mg} / 100 \mathrm{ml})$ as compared with the other hybrids followed by hybrids 9 and 10 , whereas hybrids 3 had significantly the lowest one $(6.40$ and 6.79 $\mathrm{mg} / 100 \mathrm{ml}$ ) (Table 4). In support of our results, El-Beacy (2001) reported that fruit of Florida prince peach cv. gave 9.9 and 9.0 $\mathrm{mg} / 100 \mathrm{mg}$ fresh weight for both seasons. As for, Forcada et al. (2014) cleared that the ascorbic acid content of fruit Catherine peach cultivars was 7.5 and $9.1 \mathrm{mg} / 100 \mathrm{~g} \mathrm{FW}$ in two successive seasons.

\section{Identification of peach hybrids using RAPD markers}

Eight primers of arbitrary nucleotide sequences were used to amplify DNA segments for the genomic DNA of the ten tested peach hybrids. The numbers of amplified products produced by each primer varied from 4 in primer (CA-3) to 12 in primer (OPA-8). Eight primer tested gave clearly differences among peach hybrids on the bases of amplified product patterns were illustrated in Figure (1), percentage of polymorphism were ranged from $0 \%$ up to $100 \%$ (Table 5).

Results indicated that 53 polymorphic DNA fragments (bands) were obtained out of 66 amplified DNA products, which produced by the eight primers. The remaining products, 13 bands were monomorphic shared across the ten tested hybrids. Figure (1) showed the amplified product profiles generated by primers OPA-8, OPA-13, CA-1, CA-2, CA-3, AM-1, AM-2 and AM-3 across the ten peach hybrids.

The comparison between the ten tested peach cultivars showed differences in the number and size of amplified fragments produced by each primer for each hybrid. Some bands were common among all tested hybrids while others were considered specific for hybrids.

\subsection{RAPD Analysis (Cluster Analysis):}

The RAPD markers (bands) that produced by the eight positive primers were analyzed using UPGMA method to construct a similarity 
matrix Table (6), and to generate a dendrogram indicating the relationships between the ten tested hybrids were illustrated in Figure (2). The presence or absence of any particular DNA band was a factor only considered in the computer analysis. Variations in band intensity were observed between the same bands of different hybrids but not considered in this analysis. The genetic similarities between the ten tested peach hybrids were ranged from 0.08 to 0.50 (Table 6). The values of genetic similarity obtained between hybrid 2 and each of hybrids $1,3,4,5,6,7,8,9$ and hybrid 10 were $0.40,0.28,0.10,0.08$, $0.25,0.20,0.20,0.33$ and 0.36 , respectively. The dendrogram indicated that the ten tested hybrids were classified into two main clusters (cluster I and cluster II). Cluster I included hybrids 9 and 10. The cluster II was divided in to two sub-clusters, sub-cluster I contained hybrids 1 and 3 and sub-cluster II divided into two groups, group II included hybrids 6 and 8 and group I divided into two subgroups, sub-group I divided in to two sub sub groups, sub sub group I included hybrids 2 and 5 and sub sub group II included hybrid 4 and sub-group II included hybrid 7 Figure (2). These results are similar to those reported by others Fei et al. (2003), Zimback et al. (2003), Jun et al. (2004), Haikal (2005) and Fathi et al. (2013. b).

\section{CONCLUSION}

When comparing fruit characteristics of these hybrids, all tested peach hybrids have important characters which could be considered in the current breeding programs to selected new peach strains with good nutritional quality.

\section{REFERENCES}

Abidi, W. (2016). Quality attributes and chilling injury susceptibility of new peach [Prunus Persica (L.) Batsch] cultivars grown under Tunisian conditions. J. Multi. Sci. Tech. 3:4223-4227.

Ahmed, G. A. M. (2005). Effect of foliar application of some micronutrients on fruit quality changes and storageability of Desert Red Peach cv. Ph.

D. Thesis, Fac. Agric, cairo univ.

Aly, M. M. (1988). Evaluation of some peach cultivars under Egyptian conditions. M.SC. Fac. Agri. Cairo. Univ.

Association of Official Agriculture Chemistry A.O.A.C, (1980). Official methods of analysis. 13th ed. Association of official analytical chemists. Washington, D.C., U.S.A

FAO. (2014). Food and Agriculture Organization. http://faostat.fao.org.

Cirilli, M.; D. Bassi and A. Ciacciulli (2016). Sugars in peach fruit a breeding perspective. Hort. Res. 3:15067-15078.

Citadin, I.; S. Scariotto; M. R. Sachet; F. J. Rosa; M. C. B. Raseira and A. W. Junior (2014). Adaptability and stability of fruit set and production of peach trees in a subtropical climate. Sci. Agric. 71(2):133-138. 
Dinesh, S.; Y. Gracely and K. Kumar. (2014). Performance of some low chill peach, (Prunus persica (L) Batsch) germplasm accessions for fruit quality traits in Himachal Pradesh. Inter. J. Farm. Sci. 4(3):72-80.

Doyle J.J. and J.L. Doyle (1990). A rapid DNA isolation procedure for small quantities of fresh leaf tissue. Focus, 12: 13-15.

El-Beacy, A. A. (2001) Effect of thinning and girding on yield and fruit qualities of peach. M.Sc. Thesis, Fac. of Agric, Mansoura Univ.

Eliwa, G.I. (2005).Approach to new peach cultivars by the aid of horticultural studies on Meet-Ghamr peach chosen strains. J. Agric. Sci. Mansoura Univ., 30 (8) : 4649-4663.

El-Shekh, M. H. E. (2001) Studies on breaking bud dormancy types of some low chilling requirement peach cultivars. Ph.D. Thesis, Fac. of Agric, Cairo Univ.

Emad-Eldin, A. H. A.; D. S. Assem; A. M. E. Alia and M. K. Bahan (2012). Horticultural evaluation of some new F1 peach hybrid seedlings. Aust. J. Basic \& Appl. Sci, 6(3):840-848.

Ezz, T. M. and A. M. El-Kobbia (2000) Response of Early Grand peach to chemical thinning, ethrel, gibberellic acid and urea. J. Agric. Sci. Mansoura Univ., 25 (8) : 5267-5278.

Fahmy, M. A.; G. A. Baghdady; A. M. Abd-Elrazik; G. A. Abdrabboh and E. A. Kabsha (2015). Effect of some dormancy breaking agents on fruit quality and storability of Florida prince peach under cold storage conditions. Nat. Sci. 13(1):21-26.

Fathi, H.; J. Dejampourb; U. Jahanic and M. Zarrinbald (2013 a). Tree and fruit characterization of peach genotypes grown under Ardabil and East Azerbaijan environmental conditions in Iran. J. Crop Breeding, 3(1):31-43.

Fathi, M. A.; SH. M. Hussein and S.Y. Mohamed (2013 b). Horticultural and molecular genetic evaluation of some peach selected strains cultivated under kalubiah governorate conditions. J. Amer. Sci. $9(1): 12-23$.

Fei,Q. ; LR. Wang ; CH. Fan; GR. Zhu; WC. Fang (2003). Evaluation of segregation patterns of peach in an interspecific F1 hybrids with RAPD markers. J. fruit science., 20:4, 310-312.

Forcada, C. F.; Y. Gogorcena and M. A. Moreno (2014). Agronomical parameters, sugar profile and antioxidant compounds of "Catherine" peach cultivar influenced by different plum rootstocks. Int. J. Mol. Sci. 15:2237-2254.

Gawiesh, M. S. A. S. ( 2009) Studies on hybridization between some peach varieties. M.SC. Fac. Agri. Kafrelsheikh. Univ .

Haikal, A. M. (2005). Physiological and taxonomical studies on some peach cultivars. Ph.D. Thesis, Fac. Of Agric, Alex. Univ.

Hammer Ø; D.A.T. Harper; P.D. Ryan and PAST (2001). Paleontological Statistics Software Package for Education and Data Analysis, Palaeontologia Electronica, 4: 1-9.

Holub, J. and V. Iolar (1980). Evaluation of productivity and ripening date indices in peach cultivars. Zbornik UVTIZ, Zahradnictvi (1979) 4 (1/2) 33-42. (Hort. Abst (50) No. 3. 1690). 
Jana, B. R. (2015). Performance of some low chill peach, [Prunus persica (L) Batsch] under eastern plateau regions of India. Int. J. Curr. Microbiol. App. Sci. 4(12): 752-757.

Jun, WU. ; Huai Rui Shu ; Kaichun. Zhong, Lijie. Jiang ; XiaoHong. Zhou and Cuihua. Xin (2004) Construction and analysis of peach genetic map. Acta Horticulturae sinica., 31(5): 593-597.

Shaltout, A. D. (2003) The peach industry in Egypt : State of art, Research and development. Agrigento, Italy (http://unipa.it / medpeach / proceedings $)$.

Sharpe, R.H., (1971). Florida belle: a peach for central Florida Circ. Univ. Fla. Agric. Exp. Stats 5-203, 1970, pp. 4. Hort. Abst. 41(2), 3320.

Sherman, W.B. and P.M. Lyrene. (1983). Handling seedling populations, p. 66-73. In: J.N. Moore and J. Janick (eds.). Methods in fruit breeding. Purdue Univ. Press, West Lafayette, Ind.

Shinya, P.; L. Contador; T. Frett; R. Infante (2014). Effect of prolonged cold storage on the sensory quality of peach and nectarine. Post. Bio. Tec. 95, 7-12.

Snedecor, G. W and W. Cochran (1967). Statistical methods 6th Ed. The lowa state Univ. Press. Ames lowa U.S.A. pp. 593.

Stino G. R and N. M. Mansour, (1985). Studies on seven American peach cultivars newly introduced to Egypt. Agric. Res. Rev. 65(3): 325332.

Stino G. R., N. M. Mansour and A. Hamouda (1982). Characters of four American peach cultivars grown in Egypt. Res. Bull. No 2082. Fac. Agri. Ain Shams Univ. Cairo Egypt.

Tomo, M.; M. Nebojša and G. Ivan (2012). Evaluation of fruit growth and postharvest physical and chemical properties of nectarine [Prunus persica var. nectarina (Ait.) Maxim.]. Acta Sci. Pol, 11(5):17-30.

Watada, A. E.; J. A. Abbott and E. E. J. Finney (1976). Firmness of peaches measured nondestructively J. Amer. Soc. (Hort. Sci (101) No. 4. 404-406).

Weeden, N.; G. Timmerman; M. Hemmat; F. Loaiza-Figueroa and J. Lu (1991). Evaluation and characterization of RAPD markers for genome mapping. Proc 3rd Int Congress of Plant Mol Biol 1721.

Zimback,L.; W. Barbosa ; ES. Mori and RF. De- A- Veiga (2003) Characterization and identification of tropical and Douradoa peach cultivars using RAPD markers. Revista Brasileira de Fruiticultura.; 25:2, 352-354. 
Table 1: Bud burst, full bloom, fruit set percentages and ripening date of ten experimental peach hybrids in 2014 and 2015 seasons

\begin{tabular}{|c|c|c|c|c|c|c|c|c|}
\hline \multirow{2}{*}{ Hybrids } & \multicolumn{2}{|c|}{ Bud burst date } & \multicolumn{2}{c|}{ Full bloom date } & \multicolumn{3}{c|}{ Fruit set (\%) } \\
\cline { 2 - 8 } & $\mathbf{2 0 1 4}$ & $\mathbf{2 0 1 5}$ & $\mathbf{2 0 1 4}$ & $\mathbf{2 0 1 5}$ & $\mathbf{2 0 1 4}$ & $\mathbf{2 0 1 5}$ & $\mathbf{2 0 1 4}$ & $\mathbf{2 0 1 5}$ \\
\hline $\mathbf{1}$ & $17 \mathrm{Feb}$ & $8 \mathrm{Feb}$ & $23 \mathrm{Mar}$ & $11 \mathrm{Mar}$ & $31.60 \mathrm{c}$ & $32.97 \mathrm{a}$ & $18 \mathrm{Jun}$ & $30 \mathrm{Jun}$ \\
\hline $\mathbf{2}$ & $29 \mathrm{Jan}$ & $3 \mathrm{Feb}$ & $24 \mathrm{Feb}$ & $6 \mathrm{Mar}$ & $31.60 \mathrm{c}$ & $26.57 \mathrm{~cd}$ & $30 \mathrm{May}$ & $22 \mathrm{Jun}$ \\
\hline $\mathbf{3}$ & $5 \mathrm{Feb}$ & $12 \mathrm{Feb}$ & $10 \mathrm{Mar}$ & $15 \mathrm{Mar}$ & $25.40 \mathrm{de}$ & $24.40 \mathrm{~d}$ & $10 \mathrm{Jun}$ & $15 \mathrm{Jun}$ \\
\hline $\mathbf{4}$ & $1 \mathrm{Feb}$ & $7 \mathrm{Feb}$ & $3 \mathrm{Mar}$ & $12 \mathrm{Mar}$ & $28.07 \mathrm{~d}$ & $29.50 \mathrm{~b}$ & $23 \mathrm{May}$ & $30 \mathrm{May}$ \\
\hline $\mathbf{5}$ & $28 \mathrm{Jan}$ & $20 \mathrm{Jan}$ & $28 \mathrm{Feb}$ & $18 \mathrm{Feb}$ & $26.03 \mathrm{de}$ & $25.33 \mathrm{~d}$ & $30 \mathrm{May}$ & $26 \mathrm{May}$ \\
\hline $\mathbf{6}$ & $25 \mathrm{Jan}$ & $21 \mathrm{Jan}$ & $24 \mathrm{Feb}$ & $23 \mathrm{Feb}$ & $39.00 \mathrm{a}$ & $33.90 \mathrm{a}$ & $30 \mathrm{May}$ & $26 \mathrm{May}$ \\
\hline $\mathbf{7}$ & $10 \mathrm{Feb}$ & $13 \mathrm{Feb}$ & $12 \mathrm{Mar}$ & $11 \mathrm{Mar}$ & $28.70 \mathrm{~d}$ & $27.40 \mathrm{c}$ & $29 \mathrm{Jun}$ & $15 \mathrm{Jun}$ \\
\hline $\mathbf{8}$ & $18 \mathrm{Feb}$ & $12 \mathrm{Feb}$ & $17 \mathrm{Mar}$ & $15 \mathrm{Mar}$ & $35.20 \mathrm{~b}$ & $27.33 \mathrm{c}$ & $19 \mathrm{Jun}$ & $15 \mathrm{Jun}$ \\
\hline $\mathbf{9}$ & $10 \mathrm{Feb}$ & $4 \mathrm{Feb}$ & $12 \mathrm{Mar}$ & $2 \mathrm{Mar}$ & $29.23 \mathrm{~d}$ & $30.53 \mathrm{~b}$ & $27 \mathrm{Jun}$ & $22 \mathrm{Jun}$ \\
\hline $\mathbf{1 0}$ & $8 \mathrm{Feb}$ & $9 \mathrm{Feb}$ & $6 \mathrm{Mar}$ & $7 \mathrm{Mar}$ & $24.00 \mathrm{e}$ & $25.40 \mathrm{~d}$ & $29 \mathrm{Jun}$ & $24 \mathrm{Jun}$ \\
\hline
\end{tabular}

Mean designated by the same letter in each column are not significantly different at the $5 \%$ level according to Duncans's multiple range test.

Table 2: Fruit weight $(\mathrm{g})$, size $(\mathrm{cm} 3)$, length $(\mathrm{cm})$, diameter $(\mathrm{cm})$ and shape index of ten experimental peach hybrids in 2014and 2015 seasons

\begin{tabular}{|c|c|c|c|c|c|c|c|c|c|c|}
\hline \multirow[t]{2}{*}{ Hybrids } & \multicolumn{2}{|c|}{ Fruit weight (g) } & \multicolumn{2}{|c|}{ Fruit size $\left(\mathrm{cm}^{3}\right)$} & \multicolumn{2}{|c|}{ Fruit length $(\mathrm{cm})$} & \multicolumn{2}{|c|}{ Fruit diameter $(\mathrm{cm})$} & \multicolumn{2}{|c|}{$\begin{array}{l}\text { Fruit shape index } \\
\text { (L/D ratio) }\end{array}$} \\
\hline & 2014 & 2014 & 2014 & 2015 & 2014 & 2015 & 2014 & 2015 & 2014 & 2015 \\
\hline 1 & $87.27 \mathrm{~d}$ & $88.28 d$ & $72.03 \mathrm{de}$ & $72.63 \mathrm{~d}$ & $5.46 \mathrm{c}$ & $5.57 \mathrm{~d}$ & $5.62 \mathrm{bc}$ & $5.79 \mathrm{~b}$ & $0.97 a b$ & $0.96 \mathrm{~b}$ \\
\hline 2 & $85.62 \mathrm{e}$ & $84.19 \mathrm{e}$ & $71.13 \mathrm{e}$ & $69.60 \mathrm{f}$ & $5.43 \mathrm{~cd}$ & $4.81 \mathrm{f}$ & $5.74 \mathrm{bc}$ & $5.34 \mathrm{~d}$ & $0.94 \mathrm{~cd}$ & $0.90 \mathrm{c}$ \\
\hline 3 & $92.17 \mathrm{~b}$ & $91.23 \mathrm{c}$ & $73.50 \mathrm{c}$ & $75.56 \mathrm{c}$ & $6.09 \mathrm{~b}$ & $6.01 \mathrm{~b}$ & $6.39 \mathrm{a}$ & $4.89 \mathrm{e}$ & $0.95 \mathrm{bc}$ & $1.22 \mathrm{a}$ \\
\hline 4 & $88.16 \mathrm{~cd}$ & $90.29 \mathrm{c}$ & $72.23 \mathrm{~cd}$ & $72.90 \mathrm{~d}$ & $4.83 \mathrm{e}$ & $5.46 \mathrm{~d}$ & $4.81 \mathrm{e}$ & $5.55 c$ & $1.002 \mathrm{a}$ & $0.98 \mathrm{~b}$ \\
\hline 5 & $88.94 \mathrm{c}$ & $91.26 \mathrm{c}$ & $69.00 \mathrm{f}$ & $73.23 \mathrm{~d}$ & $6.37 \mathrm{a}$ & $5.78 \mathrm{c}$ & $6.40 \mathrm{a}$ & $5.88 \mathrm{~b}$ & $0.99 \mathrm{a}$ & $0.98 \mathrm{~b}$ \\
\hline 6 & $85.48 \mathrm{e}$ & $84.91 \mathrm{e}$ & $72.76 \mathrm{~cd}$ & $70.93 \mathrm{e}$ & $4.95 \mathrm{e}$ & $5.13 \mathrm{e}$ & $5.37 d$ & $5.29 \mathrm{~d}$ & $0.92 \mathrm{~d}$ & $0.96 \mathrm{~b}$ \\
\hline 7 & $80.15 \mathrm{~g}$ & $80.08 \mathrm{f}$ & $66.13 \mathrm{~h}$ & $63.53 \mathrm{~g}$ & $5.29 \mathrm{~d}$ & $4.75 \mathrm{f}$ & $5.59 c$ & $5.23 \mathrm{~d}$ & $0.94 \mathrm{~cd}$ & $0.90 \mathrm{c}$ \\
\hline 8 & $83.03 \mathrm{f}$ & $85.40 \mathrm{e}$ & $67.46 \mathrm{~g}$ & 70.40 ef & $4.55 \mathrm{f}$ & $5.81 \mathrm{c}$ & $4.85 \mathrm{e}$ & $5.90 \mathrm{~b}$ & $0.93 \mathrm{~cd}$ & $0.98 \mathrm{~b}$ \\
\hline 9 & $95.11 \mathrm{a}$ & $93.77 \mathrm{~b}$ & $79.90 \mathrm{~b}$ & $78.93 \mathrm{~b}$ & $5.43 \mathrm{~cd}$ & $4.77 \mathrm{f}$ & $5.76 \mathrm{~b}$ & $5.31 \mathrm{~d}$ & $0.94 \mathrm{~cd}$ & $0.89 \mathrm{c}$ \\
\hline 10 & $95.88 \mathrm{a}$ & $97.35 \mathrm{a}$ & $82.26 \mathrm{a}$ & $82.86 \mathrm{a}$ & $6.33 \mathrm{a}$ & $6.29 \mathrm{a}$ & $6.39 a$ & $6.33 \mathrm{a}$ & $0.99 a b$ & $0.99 \mathrm{~b}$ \\
\hline
\end{tabular}


Table 3: Fruit firmness (g/ cm2), Seed weight (g), Flesh weight (g), Flesh/seed ratio and flesh thickness $(\mathrm{cm})$ of ten experimental peach hybrids in 2014and 2015 seasons

\begin{tabular}{|c|c|c|c|c|c|c|c|c|c|c|}
\hline \multirow{2}{*}{ Hybrids } & \multicolumn{2}{|c|}{$\begin{array}{c}\text { Fruit firmness } \\
\left(\mathbf{g} / \mathbf{c m}^{2}\right)\end{array}$} & \multicolumn{2}{|c|}{ Seed weight (g) } & \multicolumn{2}{|c|}{ Flesh weight (g) } & \multicolumn{2}{c|}{ Flesh/seed ratio } & \multicolumn{2}{c|}{$\begin{array}{c}\text { flesh thickness } \\
\text { (cm) }\end{array}$} \\
\cline { 2 - 11 } & $\mathbf{2 0 1 4}$ & $\mathbf{2 0 1 4}$ & $\mathbf{2 0 1 4}$ & $\mathbf{2 0 1 5}$ & $\mathbf{2 0 1 4}$ & $\mathbf{2 0 1 5}$ & $\mathbf{2 0 1 4}$ & $\mathbf{2 0 1 5}$ & $\mathbf{2 0 1 4}$ & $\mathbf{2 0 1 5}$ \\
\hline $\mathbf{1}$ & $469 \mathrm{a}$ & $393 \mathrm{bc}$ & $6.48 \mathrm{bc}$ & $6.56 \mathrm{c}$ & $80.74 \mathrm{~cd}$ & $81.72 \mathrm{e}$ & $12.49 \mathrm{~cd}$ & $12.48 \mathrm{bc}$ & $1.56 \mathrm{bc}$ & $1.73 \mathrm{bc}$ \\
\hline $\mathbf{2}$ & $374 \mathrm{~d}$ & $336 \mathrm{e}$ & $5.92 \mathrm{~cd}$ & $5.71 \mathrm{e}$ & $79.70 \mathrm{de}$ & $78.48 \mathrm{f}$ & $13.48 \mathrm{ab}$ & $13.74 \mathrm{ab}$ & $1.61 \mathrm{bc}$ & $1.54 \mathrm{e}$ \\
\hline $\mathbf{3}$ & $382 \mathrm{~cd}$ & $409 \mathrm{bc}$ & $6.23 \mathrm{~cd}$ & $5.99 \mathrm{de}$ & $85.94 \mathrm{~b}$ & $85.24 \mathrm{c}$ & $13.80 \mathrm{ab}$ & $14.23 \mathrm{a}$ & $1.82 \mathrm{a}$ & $1.93 \mathrm{a}$ \\
\hline $\mathbf{4}$ & $431 \mathrm{~b}$ & $383 \mathrm{~cd}$ & $6.52 \mathrm{bc}$ & $6.92 \mathrm{bc}$ & $81.64 \mathrm{c}$ & $83.37 \mathrm{de}$ & $12.69 \mathrm{~cd}$ & $12.05 \mathrm{~cd}$ & $1.66 \mathrm{~b}$ & $1.79 \mathrm{bc}$ \\
\hline $\mathbf{5}$ & $304 \mathrm{e}$ & $328 \mathrm{e}$ & $6.77 \mathrm{bc}$ & $7.22 \mathrm{~b}$ & $82.16 \mathrm{c}$ & $84.05 \mathrm{~cd}$ & $12.13 \mathrm{~cd}$ & $11.67 \mathrm{~cd}$ & $1.60 \mathrm{bc}$ & $1.71 \mathrm{~cd}$ \\
\hline $\mathbf{6}$ & $426 \mathrm{~b}$ & $456 \mathrm{a}$ & $6.18 \mathrm{~cd}$ & $5.55 \mathrm{e}$ & $79.30 \mathrm{e}$ & $79.36 \mathrm{f}$ & $12.86 \mathrm{bc}$ & $14.30 \mathrm{a}$ & $1.81 \mathrm{a}$ & $1.74 \mathrm{bc}$ \\
\hline $\mathbf{7}$ & $431 \mathrm{~b}$ & $417 \mathrm{~b}$ & $5.01 \mathrm{e}$ & $5.03 \mathrm{f}$ & $75.14 \mathrm{~g}$ & $75.06 \mathrm{~g}$ & $15.00 \mathrm{a}$ & $14.94 \mathrm{a}$ & $1.38 \mathrm{~d}$ & $1.54 \mathrm{e}$ \\
\hline $\mathbf{8}$ & $405 \mathrm{bc}$ & $377 \mathrm{~d}$ & $5.37 \mathrm{de}$ & $5.56 \mathrm{e}$ & $77.65 \mathrm{f}$ & $79.84 \mathrm{f}$ & $14.45 \mathrm{ab}$ & $14.41 \mathrm{a}$ & $1.51 \mathrm{c}$ & $1.65 \mathrm{~d}$ \\
\hline $\mathbf{9}$ & $475 \mathrm{a}$ & $476 \mathrm{a}$ & $7.19 \mathrm{ab}$ & $6.40 \mathrm{~cd}$ & $87.92 \mathrm{a}$ & $87.37 \mathrm{~b}$ & $12.23 \mathrm{~cd}$ & $13.67 \mathrm{ab}$ & $1.91 \mathrm{a}$ & $1.81 \mathrm{~b}$ \\
\hline $\mathbf{1 0}$ & $481 \mathrm{a}$ & $473 \mathrm{a}$ & $7.93 \mathrm{a}$ & $8.12 \mathrm{a}$ & $87.95 \mathrm{a}$ & $89.23 \mathrm{a}$ & $11.19 \mathrm{~d}$ & $10.99 \mathrm{~d}$ & $1.92 \mathrm{a}$ & $1.83 \mathrm{~b}$ \\
\hline
\end{tabular}

Mean designated by the same letter in each column are not significantly different at the $5 \%$ level according to Duncans's multiple range test. 


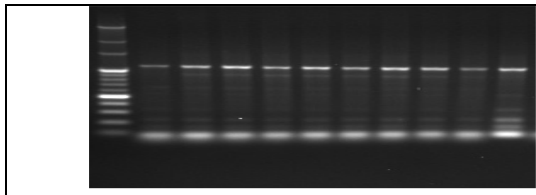
opA8

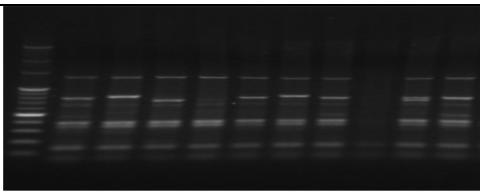

opA13

Table 4: SSC (\%), Acidity (\%), SSC/acidity ratio and Vitamin C (mg/100ml) of ten experimental peach hybrids in 2014 and 2015 seasons

\begin{tabular}{|c|c|c|c|c|c|c|c|c|}
\hline \multirow{2}{*}{ Hybrids } & \multicolumn{2}{|c|}{ SSC (\%) } & \multicolumn{2}{c|}{ Acidity (\%) } & \multicolumn{2}{c|}{ SSC/acidity ratio } & \multicolumn{2}{c|}{ Vitamin C (mg/100ml ) } \\
\cline { 2 - 8 } & $\mathbf{2 0 1 4}$ & $\mathbf{2 0 1 5}$ & $\mathbf{2 0 1 4}$ & $\mathbf{2 0 1 5}$ & $\mathbf{2 0 1 4}$ & $\mathbf{2 0 1 5}$ & $\mathbf{2 0 1 4}$ & $\mathbf{2 0 1 5}$ \\
\hline $\mathbf{1}$ & $9.33 \mathrm{e}$ & $9.56 \mathrm{e}$ & $0.755 \mathrm{a}$ & $0.745 \mathrm{a}$ & $12.35 \mathrm{f}$ & $12.84 \mathrm{~g}$ & $7.68 \mathrm{e}$ & $8.45 \mathrm{e}$ \\
\hline $\mathbf{2}$ & $12.23 \mathrm{bc}$ & $12.40 \mathrm{~b}$ & $0.578 \mathrm{f}$ & $0.588 \mathrm{e}$ & $21.15 \mathrm{c}$ & $21.07 \mathrm{bc}$ & $6.82 \mathrm{~g}$ & $7.43 \mathrm{f}$ \\
\hline $\mathbf{3}$ & $13.33 \mathrm{a}$ & $13.43 \mathrm{a}$ & $0.485 \mathrm{i}$ & $0.520 \mathrm{~h}$ & $27.49 \mathrm{a}$ & $25.80 \mathrm{a}$ & $6.40 \mathrm{~h}$ & $6.79 \mathrm{~g}$ \\
\hline $\mathbf{4}$ & $11.96 \mathrm{bc}$ & $12.10 \mathrm{~b}$ & $0.620 \mathrm{e}$ & $0.612 \mathrm{~d}$ & $19.30 \mathrm{~d}$ & $19.77 \mathrm{~cd}$ & $7.81 \mathrm{e}$ & $8.43 \mathrm{e}$ \\
\hline $\mathbf{5}$ & $11.03 \mathrm{~d}$ & $11.30 \mathrm{~cd}$ & $0.630 \mathrm{e}$ & $0.624 \mathrm{~d}$ & $17.50 \mathrm{e}$ & $18.08 \mathrm{ef}$ & $7.48 \mathrm{f}$ & $8.77 \mathrm{~d}$ \\
\hline $\mathbf{6}$ & $9.50 \mathrm{e}$ & $9.50 \mathrm{e}$ & $0.710 \mathrm{~b}$ & $0.729 \mathrm{~b}$ & $13.37 \mathrm{f}$ & $13.02 \mathrm{~g}$ & $8.42 \mathrm{~d}$ & $9.26 \mathrm{c}$ \\
\hline $\mathbf{7}$ & $11.00 \mathrm{~d}$ & $10.96 \mathrm{~d}$ & $0.678 \mathrm{c}$ & $0.650 \mathrm{c}$ & $16.22 \mathrm{e}$ & $16.88 \mathrm{f}$ & $9.60 \mathrm{a}$ & $10.27 \mathrm{a}$ \\
\hline $\mathbf{8}$ & $12.60 \mathrm{ab}$ & $12.76 \mathrm{ab}$ & $0.528 \mathrm{~h}$ & $0.572 \mathrm{f}$ & $23.85 \mathrm{~b}$ & $22.32 \mathrm{~b}$ & $8.72 \mathrm{c}$ & $9.16 \mathrm{c}$ \\
\hline $\mathbf{9}$ & $11.60 \mathrm{~cd}$ & $12.00 \mathrm{bc}$ & $0.659 \mathrm{~d}$ & $0.649 \mathrm{c}$ & $17.59 \mathrm{e}$ & $18.48 \mathrm{de}$ & $9.29 \mathrm{~b}$ & $9.87 \mathrm{~b}$ \\
\hline $\mathbf{1 0}$ & $11.56 \mathrm{~cd}$ & $12.23 \mathrm{~b}$ & $0.561 \mathrm{~g}$ & $0.553 \mathrm{~g}$ & $20.59 \mathrm{~cd}$ & $22.12 \mathrm{~b}$ & $9.38 \mathrm{~b}$ & $9.75 \mathrm{~b}$ \\
\hline
\end{tabular}

Mean designated by the same letter in each column are not significantly different at the $5 \%$ level according to Duncans's multiple range test.

Table 5: Nucleotide sequences of the eight used primers, number of amplified, polymorphic products and the percentage of polymorphism

\begin{tabular}{|c|c|c|c|c|}
\hline Primers & Nucleotide sequences & $\begin{array}{c}\text { No. of amplified } \\
\text { products (a) }\end{array}$ & $\begin{array}{c}\text { No. of } \\
\text { polymorphic } \\
\text { products (b) }\end{array}$ & $\begin{array}{c}\text { Polymorphism (\%) } \\
(\mathbf{b} / \mathbf{a} \text { x100) }\end{array}$ \\
\hline OPA-8 & GAACACTGGG & 12 & 10 & 83.3 \\
\hline OPA-13 & CAGCACCCAC & 11 & 9 & 81.8 \\
\hline CA-1 & AGGTCACTGA & 1 & 0 & 0 \\
\hline CA-2 & AAGGATCAGA & 8 & 5 & 62.5 \\
\hline CA-3 & CACATGCTTC & 4 & 2 & 50.5 \\
\hline AM-1 & GCTATGCAATGGCAG & 11 & 9 & 81.8 \\
\hline AM-2 & GGATGGAATAGTCTC & 9 & 8 & 88.8 \\
\hline AM-3 & CCTGATTTGGTAATA & 10 & 10 & 100.0 \\
\hline
\end{tabular}

Table 6: Distance matrix among ten peach genotypes (hybrids)

\begin{tabular}{|c|c|c|c|c|c|c|c|c|c|}
\hline $\mathbf{0 . 0 0}$ & $\mathbf{1}$ & $\mathbf{2}$ & $\mathbf{3}$ & $\mathbf{4}$ & $\mathbf{5}$ & $\mathbf{6}$ & $\mathbf{7}$ & $\mathbf{8}$ & $\mathbf{9}$ \\
\hline $\mathbf{1}$ & 0.00 & & & & & & & \\
\hline $\mathbf{2}$ & 0.40 & 0.00 & & & & & & \\
\hline $\mathbf{3}$ & 0.28 & 0.28 & 0.00 & & & & & \\
\hline $\mathbf{4}$ & 0.30 & 0.10 & 0.15 & 0.00 & & & & \\
\hline $\mathbf{5}$ & 0.33 & 0.08 & 0.28 & 0.10 & 0.00 & & & & \\
\hline $\mathbf{6}$ & 0.50 & 0.25 & 0.43 & 0.22 & 0.20 & 0.00 & & & \\
\hline $\mathbf{7}$ & 0.36 & 0.20 & 0.36 & 0.22 & 0.15 & 0.22 & 0.00 & & \\
\hline $\mathbf{8}$ & 0.36 & 0.20 & 0.30 & 0.17 & 0.15 & 0.13 & 0.17 & 0.00 & \\
\hline $\mathbf{9}$ & 0.33 & 0.33 & 0.46 & 0.36 & 0.28 & 0.43 & 0.36 & 0.30 & 0.00 \\
\hline $\mathbf{1 0}$ & 0.50 & 0.36 & 0.50 & 0.33 & 0.25 & 0.46 & 0.28 & 0.40 & 0.25 \\
\hline
\end{tabular}




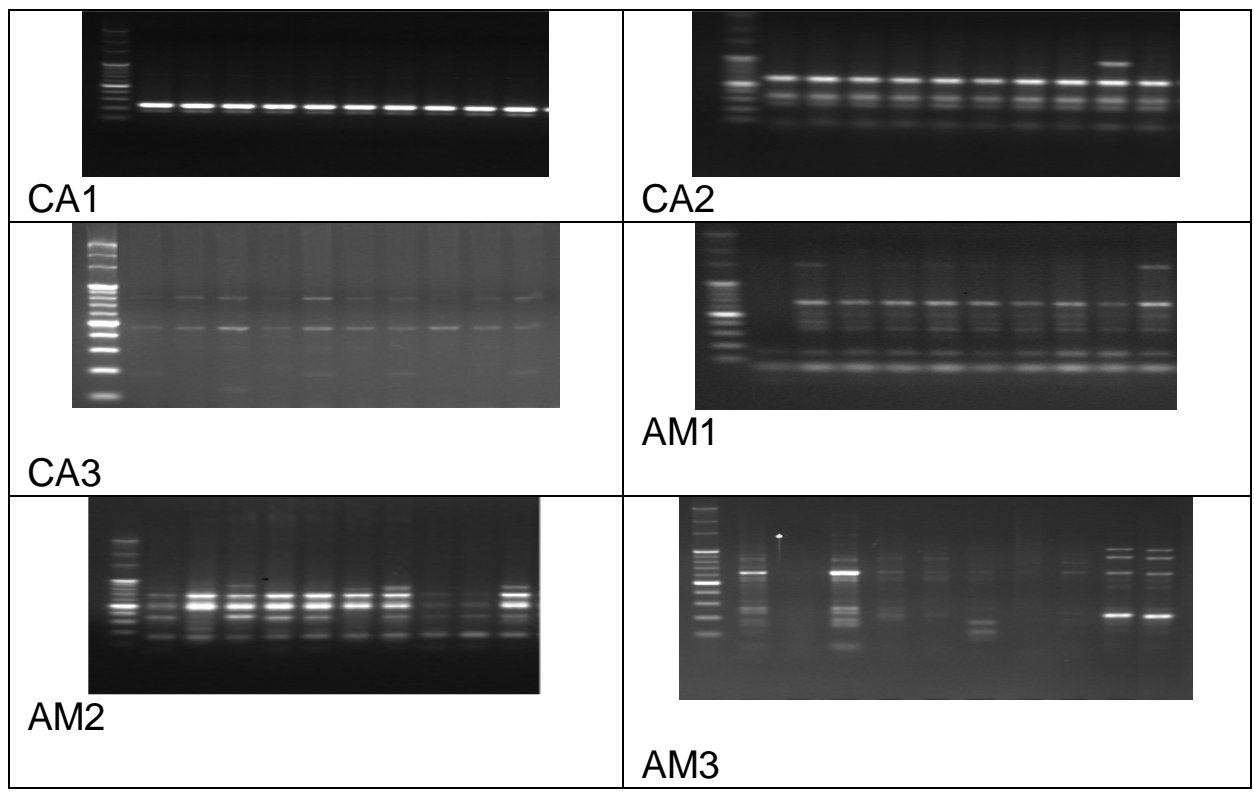

Fig. 1: RAPD fragments amplified from genomic DNA of the ten tested hybrids generated by primers

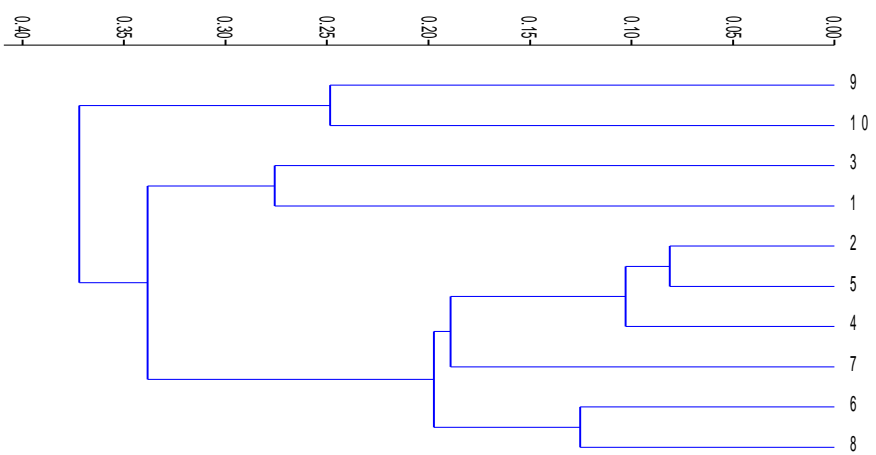

Fig. 2: Phylogenetic tree among ten hybrids peach based on eight RAPD markers 


\title{
تقييم بعض هجن الخوخ بإستخدام بعض الصفات الثمرية وتقنية RAPD
}

\author{
فاروق عبد الحميذ المرشدى ، محى الاين ابراهيم سلامه ، حمديه مصطقى عياد ، عبد

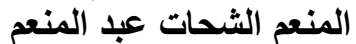 \\ قسم البساتين ، كلية الزراعة ، جامعة كفر الثيخ الثمب ر مصر.

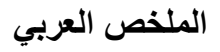

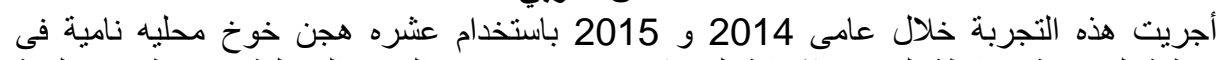

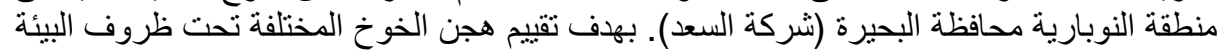

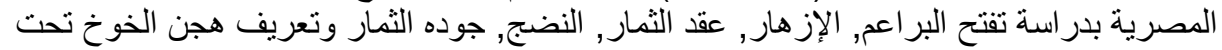

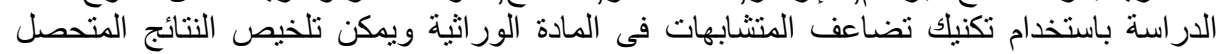
عليها فى النقاط التالية: الهجين الخامس والسادس كانا مبكران فى تفتح البراعم والإزهار الكامل بينما الثامن والأول كانا متأخر ان. وجد أيضا أن الهجين الرابع فى الموسم الأول وكلا من الخامس والسادس فى الموسم الثانى

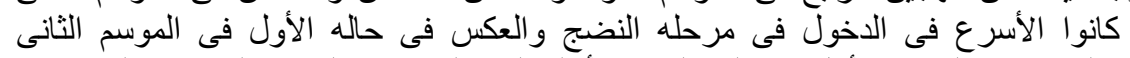

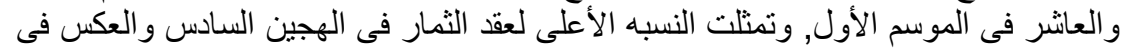

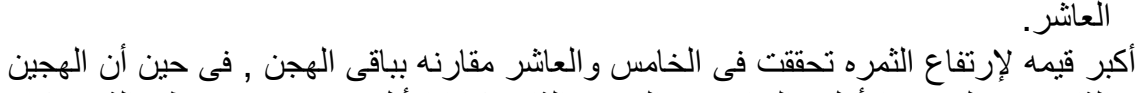

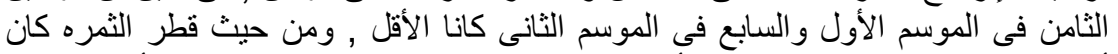

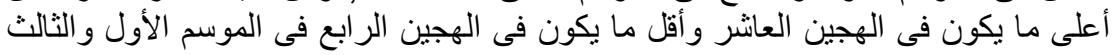

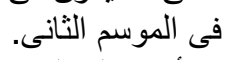

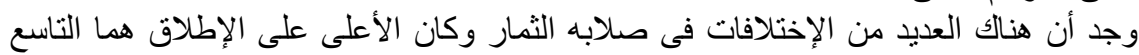

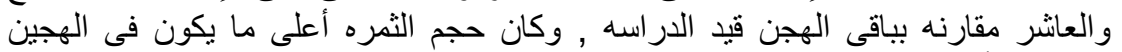

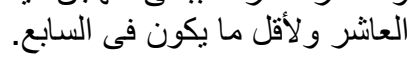

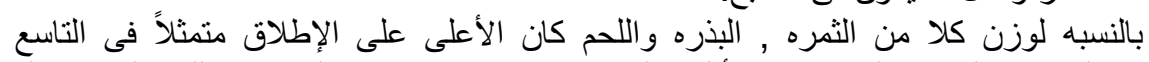

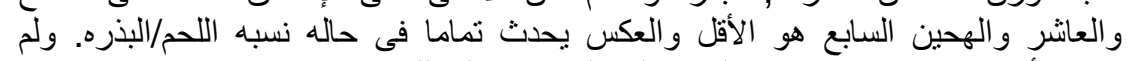

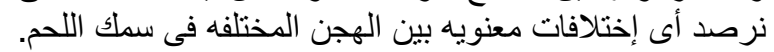

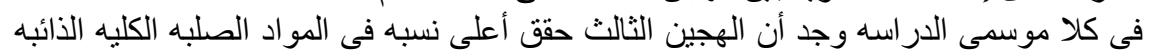

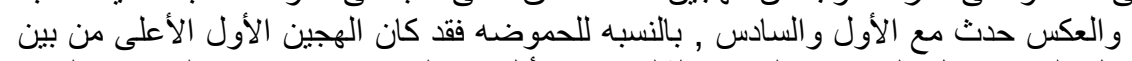

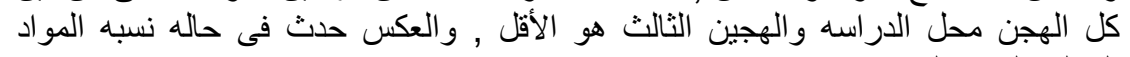

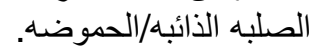
أوضحت النتائج أن الهجين السابع حقق أعلى نسبه فى حمض الإسكوربيك و العكس فى حاله

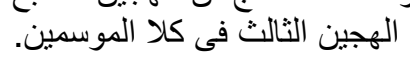

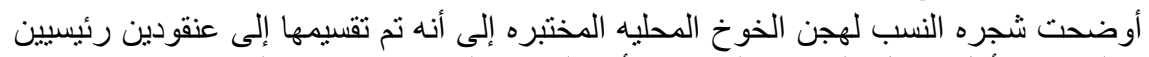

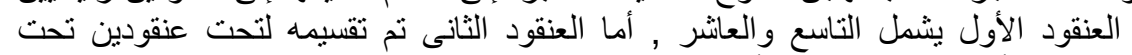

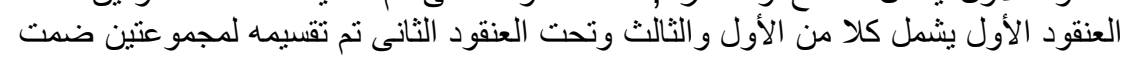

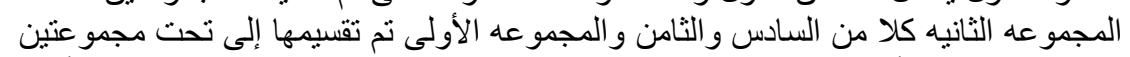

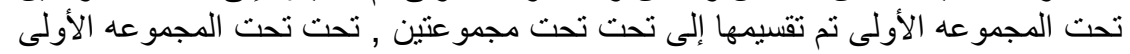

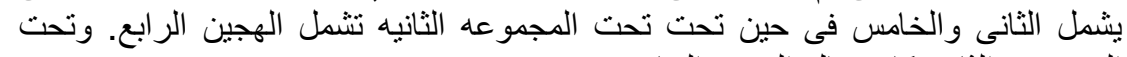

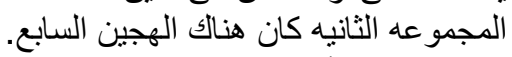

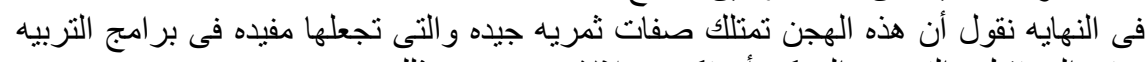

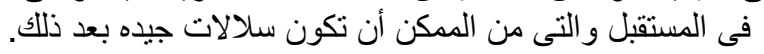

